\title{
Anti-spasmodic action of crude methanolic extract and a new compound isolated from the aerial parts of Myrsine africana
}

\author{
Sadiq Azam, Shumaila Bashir ${ }^{2}$ and Bashir Ahmad ${ }^{1 *}$
}

\begin{abstract}
Background: Myrsine africana is an herbaceous plant that is traditionally used as appetizer and carminative. Locally, it is used for the treatment of pulmonary tuberculosis, rheumatism and diarrhea by healers. The aims of the current study were to screen the crude methanol extract obtained from the aerial parts (leaves and stem) of M. africana, for antispasmodic actions on isolated tissues and further to subject the ethyl acetate (EtOAc) fraction of plant to column chromatography for isolation of pure compounds.

Methods: The antispasmodic action of the crude methanol extract was measured on the spontaneous rabbit's jejunum preparations at concentration $0.01,0.03,0.1,0.3,1.0,5.0$ and $10.0 \mathrm{mg} / \mathrm{ml}$. The crude extract was also applied, in similar concentrations, on $\mathrm{KCl}(80 \mathrm{mM})$ induced contractions to explain its possible mode of action.

Results: A new compound Myrsigenin was isolated from the EtOAc fraction of $M$. africana. The structure of the compound was identified with the help of ${ }^{13} \mathrm{C}-\mathrm{NMR},{ }^{1} \mathrm{H}-\mathrm{NMR}, \mathrm{HMBC}, \mathrm{HMQC}$, NOESY and COSY. The plant crude methanol extract showed a significant antispasmodic action on rabbit jejunum and abolished the tissue contraction completely at concentration of $5.0 \mathrm{mg} / \mathrm{ml}$.

Conclusion: The study concludes that the methanol crude extract of aerial parts of $M$. africana has antispasmodic action possibly through the calcium channel blocking mechanisms. A new compound Myrsigenin was isolated from the EtOAc fraction of the plant.
\end{abstract}

Keywords: Myrsine africana, Antispasmodic action, Myrsigenin, Rabbit jejunum, $\mathrm{KCl}$ induced contractions

\section{Background}

Plants play an important role in many cultures. Human being uses these plants in the form of sheltering, clothing, feeding, hunting and nursing for their basic requirements. Plants are the basic source of medicines in the traditional system that provides mankind new remedies for different disease(s). Recently interest in the folk medicine has highly increased and gained a scientific basis for the appropriate use in official medicines [1]. Due to unique biodiversity and salubrious climate, Pakistan is quite rich in medicinal herbs which are scattered over a large area. There are up to 6,000 wild plant species out of which 400-600 are medicinally important [2].

\footnotetext{
* Correspondence: bashirdr2001@yahoo.com

'Pharmabiotech Research Lab, Centre for Biotechnology and Microbiology,

University of Peshawar, Peshawar, Khyber Pakhtunkhwa, Pakistan

Full list of author information is available at the end of the article
}

In continuation to our previous work [3-5] the present work was carried out on M. africana (Myrsinaceae), locally called Babrang. Myrsinaceae is a large family of about 35 genera and 1000 species, widely distributed in tropical and subtropical regions [6]. Traditionally $M$. africana is used as fragrance in tea, appetizer, carminative, spices and flavoring agent. The fruits are edible and locally used as an anthelmintic. It is also used for the treatment of rheumatism, pulmonary tuberculosis, diarrhea, hemorrhage and toothache [7-11]. In powder form, the dried fruits of the plants are taken daily (once at bedtime) with a cup of curd for 3-4 days for intestinal worms. Decoction of fresh leaves is taken orally daily (twice) for 6-7 days during scanty urination, skin allergy, boils and to purify blood [12]. It has been reported that the chloroform $\left(\mathrm{CHCl}_{3}\right)$ fraction of $M$. africana possess moderate phytotoxic activity (31.25\%) against Lemna

\section{C) Biomed Central}


minor $\mathrm{L}$ at higher concentration [4]. The methanol extract and $\mathrm{CHCl}_{3}$ fraction showed good antibacterial activity against Klebsiella pneumoniae $\left(\mathrm{MIC}_{50}=2.45\right.$ and $2.1 \mathrm{mg} / \mathrm{ml}$, respectively). A moderate haemagglutination effect was shown by the methanol extract and $\mathrm{CHCl}_{3}$ fraction against human red blood cells (RBCs) of blood group $\mathrm{AB}^{-}$and same moderate effect was observed for aqueous fraction against $\mathrm{AB}^{+}$[4]. Significant inhibitory activities were shown by the alcoholic extract of leaves and twigs of the plants against walker intramuscular carcinosarcoma in rats [13]. The mixture of leaves and dried fruits of the plant in water has shown $77 \%$ efficacy against Trichostrogylus, Haemonchus and Oesophagostomum spps [14].

The phytochemical investigations revealed that the plant contains various groups of natural compounds; triterpenes, benzoquinones, flavonoids and steroids [15-20]. This manuscript deals with isolation and characterization of the compound with a six membered rings $\mathrm{E}$ and five membered $\mathrm{F}$ ring spiro fused compound isolated from $M$. africana and screening of the crude methanol extract of plant for anti-spasmodic action on isolated rabbit's jejunum.

\section{Methods}

\section{General Experimental Procedure}

Jeol JMS 600 and HX 110 mass spectrometers with the data system DA 5000 were used to record HREI-MS. The ${ }^{1} \mathrm{H}$-NMR spectrum was recorded in $\mathrm{CDCl}_{3}$ on Bruker AMX-400 and AMX-500 NMR spectrometers with TMS as an internal standard using a UNIX operating system at 400 and $500 \mathrm{MHz}$, respectively. The ${ }^{13} \mathrm{C}$-NMR spectrum was recorded at $100 \mathrm{MHz}$ on a Bruker AMX-500 NMR spectrometer in $\mathrm{CDCl}_{3}$. The $[\alpha] \mathrm{D}$ was recorded on Jasco P-2000 polarimeter. JASCO J-810 spectropolarimeter was used to record CD spectrum. Silica gel (230-270 mesh) was used for Column Chromatography (CC). Silica gel coated TLC card (GF-254, $20 \times 20 \mathrm{~cm}, 0.25 \mathrm{~mm}$ thick, Merck) were used to check the purity of compound and were observed under UV light (254 and $366 \mathrm{~nm}$ ) and ceric sulphate was used as a spraying reagent.

\section{Collection, Extraction and Fractionation}

The whole aerial parts (leaves and stem) of $M$. africana were collected from Attar Sheesha, Hazara division, in December 2007-January 2008. Prof. Dr. Habib Ahmad, Plant Taxonomist, Hazara University, Khyber Pakhtunkhwa, identified the plant.

The plant materials were shade dried, chopped and ground to fine powder by using electric grinder. The powdered materials $(7.6 \mathrm{~kg})$ were then soaked (twice) in commercial grade methanol for 15 days at room temperature with occasional shaking. After 15 days methanol soluble materials were filtered off. All the filtrates were concentrated under vacuum at $40^{\circ} \mathrm{C}$ using a rotary evaporator till a blackish crude methanol extract was obtained.

The crude methanol extract obtained was suspended in distilled water $(400 \mathrm{ml})$ and partitioned with $n$-hexane $(3 \times 400 \mathrm{ml}), \mathrm{CHCl}_{3}(3 \times 400 \mathrm{ml})$, EtOAc $(3 \times 400 \mathrm{ml})$ and $\mathrm{BuOH}(3 \times 400 \mathrm{ml})$ to yield $n$-hexane $(50 \mathrm{~g}), \mathrm{CHCl}_{3}$ $(45 \mathrm{~g})$, EtOAc $(255 \mathrm{~g}), \mathrm{BuOH}(190 \mathrm{~g})$ and aqueous (210 g) fractions. 50 gram of crude extract was reserved for pharmacological/biological activities.

\section{Effects On Rabbit's Jejunum Preparations}

Our present study was done on isolated rabbit's jejunum tissues to explore the plant extract for possible spasmolytic activity.

\section{Drugs, standards and solution preparation}

Acetylcholine (BDH Chemicals, Poole, England), Atropine and rest of the chemicals (E. Merck Germany) used in the experiments were of analytical grade. All solutions were freshly prepared in distilled water on the same day of the experiment.

Stock solutions of acetylcholine $\left(10^{-2} \mu \mathrm{M}\right)$ and $\mathrm{KCl}$ were prepared. The acetylcholine solution was diluted upto $10^{-4} \mu \mathrm{M}$ by serial dilution of the stock solution and final concentration of the $\mathrm{KCl}$ solution was made 80 $\mathrm{mM}$ in bath solution. The stock solution of sample (crude methanol extract) was prepared in distilled water by suspending $300 \mathrm{mg} / \mathrm{ml}$ and serially diluted up to 30 and $3 \mathrm{mg} / \mathrm{ml}$.

\section{Animals and data recording}

Rabbits either male or female (local breed; weight in $\mathrm{Kg}$ 1.0 - 1.4) were used in the experiments. The rabbits were maintained at the "Animal House of University of Malakand" according to the standards mentioned in the "Animals Bylaws 2008 of the University of Malakand (Scientific Procedures Issue-1)". The ethics committee of the University of Malakand approved this study (Vid case \# UOM/EC/02/2008). The protocols comply with the Byelaws 2008 of the University of Malakand that deal with scientific procedures for experimental work on animals. All of the rabbits were fed with standard diet and tap water. They were given only water, 24 hours prior to start experiments. The tissue responses were noted by Teaching Force Transducer (Model No: MLT 0210/A Pan Lab S.I.) attached with Power lab (Model No: 4/25 T) ADInstruments, Australia. Range for recording the data was $20 \mathrm{mv}$, Low pass $5 \mathrm{~Hz} \times 10$ gain using input 1 at rate $40 / \mathrm{S}$.

\section{Rabbit's jejunum preparations}

The tissue preparation for the experiments was carried out through following procedure [21]. 
1. The rabbits maintained at animal house were sacrificed and the jejunum portion(s) of the rabbits were isolated. The carbogen gas $\left(5 \% \mathrm{CO}_{2}\right.$ and $\mathrm{O}_{2}$ mixture) was used to aerate these isolated tissues placed in Tyrode's solution. The constituents and their concentrations $(\mathrm{mM})$ used in Tyrode's solution were: $\mathrm{KCl} 2.68, \mathrm{NaCl}$ 136.9, $\mathrm{MgCl}_{2}$ 1.05, $\mathrm{NaHCO}_{3}$ 11.90, $\mathrm{NaH}_{2} \mathrm{PO}_{4}$ 0.42, $\mathrm{CaCl}_{2} 1.8$ and glucose 5.55 [22-25].

2. $1.5 \mathrm{~cm}$ pieces of jejunum, maintained in the Tyrode's, were mounted in $10 \mathrm{ml}$ tissue bath maintained at $37^{\circ} \mathrm{C}$ in Tyrode's solution aerated with carbogen gas.

3. Tension (one gram) was applied on tissue. Earlier, by giving the sub-maximal doses of acetylcholine $(0.3$ $\mu \mathrm{M})$ to the tissue for keeping it undisturbed and stabilized for an equilibrium period of 30 minutes and to produce a reproducible response (normal response).

4. The plant crude methanol extract at concentration (s) of $0.01,0.03,0.1,0.3,1.0,5.0$ and $10 \mathrm{mg} / \mathrm{ml}$ were tested for the possible spasmolytic activity throughout experiments.

\section{Spasmolytic activity}

The highly concentrated $\mathrm{K}^{+}$solution $(80 \mathrm{Mm})$ was used to treat tissues in order to depolarize it and to get them in position of sustained concentration [26]. The test samples were then applied on those pre-treated tissues mounted in tissue bath, in cumulative manner, to obtain a concentration dependent response curve and their relaxation was expressed as percent of the $\mathrm{K}^{+}$induced contractions [27].

\section{Results and Discussion}

A new compound Myrsigenin was isolated as white powder from the EtOAc fraction of $M$. africana eluting with EtOAc/n-hexane (0.3:9.7) as mobile phase on flash silica column. Its optical rotation, $\left\{[\alpha]_{\mathrm{D}}{ }^{25}=-16.10\right.$ $(\mathrm{MeOH}, \mathrm{c}=0.2)\}$ indicated the presence of chiral center in molecule. HR-ESIMS displayed quasi molecular ion at $\mathrm{m} / \mathrm{z}$ 415.3217, corresponding to the formula $\mathrm{C}_{27} \mathrm{H}_{42} \mathrm{O}_{3}$ (cal. $\mathrm{C}_{27} \mathrm{H}_{42} \mathrm{O}_{3}+\mathrm{H}=415.3212$ ).

${ }^{1} \mathrm{H}-\mathrm{NMR}$ spectrum exhibited resonances at $\delta 0.72 \mathrm{~d}$ $\left(J_{21},{ }_{20}=6.5 \mathrm{~Hz}\right.$ ), 0.80 (singlet), $0.95\left(\mathrm{~d}, J_{27,24}=6.5 \mathrm{~Hz}\right)$ and $1.06 \mathrm{ppm}$ (singlet), which were assigned to the $\mathrm{C}$ 21, C-19, C-27 and C-18 methyl protons, respectively. Downfield methine protons at $\delta 3.44$ (m, broad) $\left(\mathrm{W}_{1 / 2}=\right.$ $12.5 \mathrm{~Hz})$ and $4.39(\mathrm{q}, \mathrm{J}=6.5 \mathrm{~Hz}$ ) were attributed to the $\mathrm{H}-3$ and $\mathrm{H}-16$ respectively. Resonances at $\delta 3.35$ (m) and $3.42(\mathrm{~m})$ were ascribed to the methylene protons of the C-27: this revealed the presence of oxygenated methylene carbon in molecule. A down field signal resonated at $\delta 5.33$ br d $\left(J_{6,7}=5.0\right)$, was due to the H- 6 .

${ }^{13} \mathrm{C}$-NMR spectrum (BB, DEPT) displayed twenty seven carbons including: four methyl, ten methylene, nine methine and four quaternary carbon atoms
(Table 1 ). ${ }^{1} \mathrm{H}$ and ${ }^{13} \mathrm{C}$-NMR clearly indicated that the compound has steroidal skeleton. ${ }^{13} \mathrm{C}$-NMR values at $\delta$ $67.9\left(\mathrm{CH}_{2}\right), 82.2(\mathrm{CH})$ and $110.5(\mathrm{q} \mathrm{C})$, indicated the presence of dioxygenated spiro ring as a side chain of the molecule. Structure of compound was further confirmed with the help of two dimensional NMR spectroscopic techniques including: COSY, HSQC, HMBC and NOESY. COSY and HMBC revealed that ring $\mathrm{E}$ is a six membered, while the ring $\mathrm{F}$ is a five membered. $\mathrm{H}-16$ showed cross peaks in COSY spectrum with $\mathrm{H}-17$, which in turn showed correlation with $\mathrm{H}-20$, this spin system extended up to the C-22 methylene protons. This clearly indicated that ring $\mathrm{E}$ is six membered. Similarly, H2-26 showed cross peaks on COSY spectrum with $\mathrm{H}_{2}-25$, which in turn showed correlation with $\mathrm{H}$ 24 , this spin system extended up to C-27 methyl protons, this further supported that ring $\mathrm{E}$ is six membered and ring $\mathrm{F}$ is five membered. Different spin systems, hetero atoms and functionalities were assembled using HMBC interactions. $\mathrm{H}-16, \mathrm{H}_{2}-26$ and $\mathrm{H}_{3}-27$ displayed

Table $1{ }^{1} \mathrm{H}$ and ${ }^{13} \mathrm{C}-\mathrm{NMR}$ and Chemical Shifts of compound (ppm, $\mathrm{CDCl}_{3}, 500$ and $100 \mathrm{MHz}$, respectively)

\begin{tabular}{|c|c|c|c|}
\hline $\begin{array}{l}\text { C. } \\
\text { No }\end{array}$ & $\begin{array}{l}\text { Multiplicity } \\
\text { (DEPT) }\end{array}$ & $\begin{array}{l}{ }^{13} \mathrm{C}- \\
\text { NMR }\end{array}$ & ${ }^{1} \mathrm{H}(J=\mathrm{Hz})$ \\
\hline 1 & $\mathrm{CH} 2$ & 38.5 & $1.71(\mathrm{~m} \#$ of $\mathrm{H}), 1.93(\mathrm{~m}, \#$ of $\mathrm{H})$ \\
\hline 2 & $\mathrm{CH} 2$ & 32.3 & $1.59 \mathrm{~m}, 1.83 \mathrm{~m}$ \\
\hline 3 & $\mathrm{CH}$ & 72.4 & $3.44 \mathrm{br} \mathrm{m}\left(w_{1 / 2}=12.5\right)$ \\
\hline 4 & $\mathrm{CH} 2$ & 43.0 & $2.21 \mathrm{dd}, 2.23 \mathrm{dd}$ \\
\hline 5 & $C$ & 140.8 & -——— \\
\hline 6 & $\mathrm{CH}$ & 121.8 & 5.53 br d (5.0) \\
\hline 7 & $\mathrm{CH} 2$ & 32.8 & $1.81 \mathrm{~m}, 1.97 \mathrm{~m}$ \\
\hline 8 & $\mathrm{CH}$ & 31.8 & $1.61 \mathrm{~m}$ \\
\hline 9 & $\mathrm{CH}$ & 51.7 & $0.95 \mathrm{~m}$ \\
\hline 10 & $C$ & 36.5 & -——- \\
\hline 11 & $\mathrm{CH} 2$ & 22.0 & $1.01 \mathrm{~m}, 1.42 \mathrm{~m}$ \\
\hline 12 & $\mathrm{CH} 2$ & 40.9 & $1.69 \mathrm{~m}, 1.40 \mathrm{~m}$ \\
\hline 13 & $C$ & 41.3 & -——- \\
\hline 14 & $\mathrm{CH}$ & 57.8 & $1.09 \mathrm{~m}$ \\
\hline 15 & $\mathrm{CH} 2$ & 32.7 & $1.49 \mathrm{~m}, 1.63 \mathrm{~m}$ \\
\hline 16 & $\mathrm{CH}$ & 82.2 & 4.39 q like (7.5) \\
\hline 17 & $\mathrm{CH}$ & 63.7 & $1.75 \mathrm{~m}$ \\
\hline 18 & $\mathrm{CH} 3$ & 19.8 & $1.06 \mathrm{~s}$ \\
\hline 19 & $\mathrm{CH} 3$ & 14.9 & $0.80 \mathrm{~s}$ \\
\hline 20 & $\mathrm{CH}$ & 29.9 & $1.60 \mathrm{~m}$ \\
\hline 21 & $\mathrm{CH} 3$ & 17.5 & $0.72 \mathrm{~d}\left(J_{21,20}=6.5\right)$ \\
\hline 22 & $\mathrm{CH} 2$ & 33.2 & $\begin{array}{c}1.2 \mathrm{dd} \text { (overlapped), } 1.50 \mathrm{dd} \\
\text { (overlapped) }\end{array}$ \\
\hline 23 & C & 110.5 & -——- \\
\hline 24 & $\mathrm{CH}$ & 42.9 & $1.84 \mathrm{dd}(5.5,4.5)$ \\
\hline 25 & $\mathrm{CH} 2$ & 32.4 & 1.65 m, 1.81 m \\
\hline 26 & $\mathrm{CH} 2$ & 67.9 & 3.35 m, 3.42 m \\
\hline 27 & $\mathrm{CH} 3$ & 16.8 & $0.95 \mathrm{~d}\left(J_{27,24}=6.5\right)$ \\
\hline
\end{tabular}




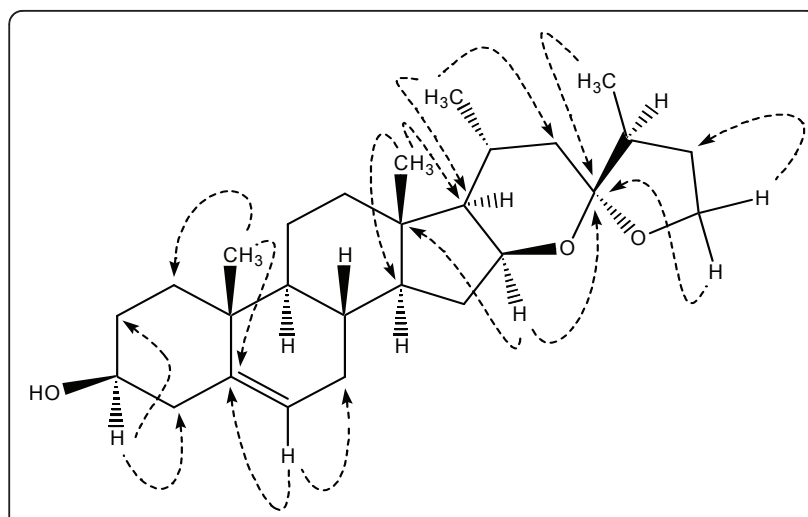

Figure 1 Key $\mathrm{HMBC}$ interactions in Myrsigenin

HMBC correlation with $\mathrm{C}-23$. While $\mathrm{H}_{3}-21$ exhibited correlation with C-22, C-20 and C-17. Key HMBC interactions in compound are shown in Figure 1.

Stereochemistry in compound was assigned on the basis of biogenesis pathway, coupling constant values and NOESY spectroscopy. H-16 displayed NOESY interactions with $\mathrm{H}-26, \mathrm{H}-14$ and $\mathrm{H}-17$, this indicated that cis ring fusion between ring $\mathrm{D}$ and $\mathrm{E}$, and $\mathrm{H}-16$ and $\mathrm{H}-$ 26 are close in space. Key NOESY interactions in compound are shown in Figure 2. CD spectrum indicates an intense positive cotton effect at $210 \mathrm{~nm}$. This type of six membered rings $\mathrm{E}$ and five membered $\mathrm{F}$ ring spiro fused compound is not so common, this compound is believed to have been biosynthesized from C-27 [28].

\section{Effects On Rabbit'S Jejunum Preparations Spasmolytic activity}

It is evident from Figure 3 that methanol extract produced a concentration dependent fall in spontaneous rabbit's jejunum preparations. The extract totally abolished the spontaneous contractions of tissues at concentration $5.0 \mathrm{mg} / \mathrm{ml}$. This confirms that the plant specie contains spasmolytic constituents and therefore has antispasmodic action.

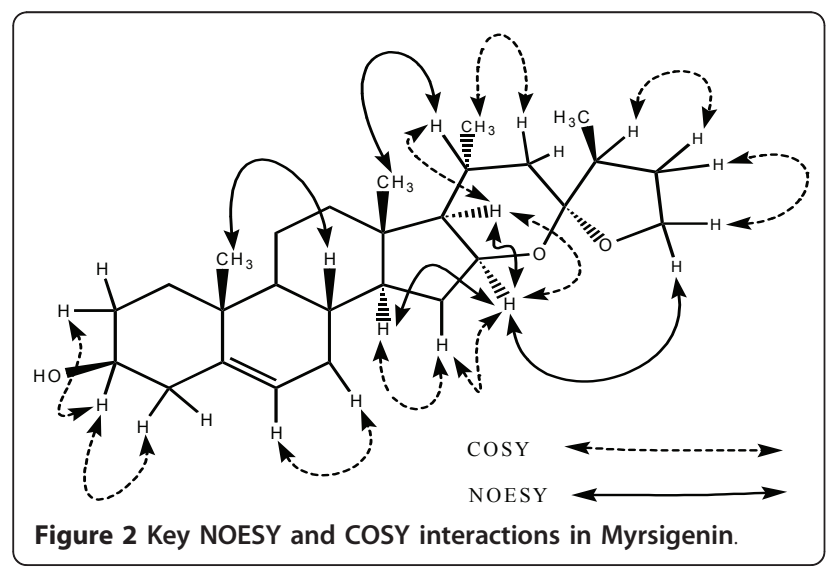

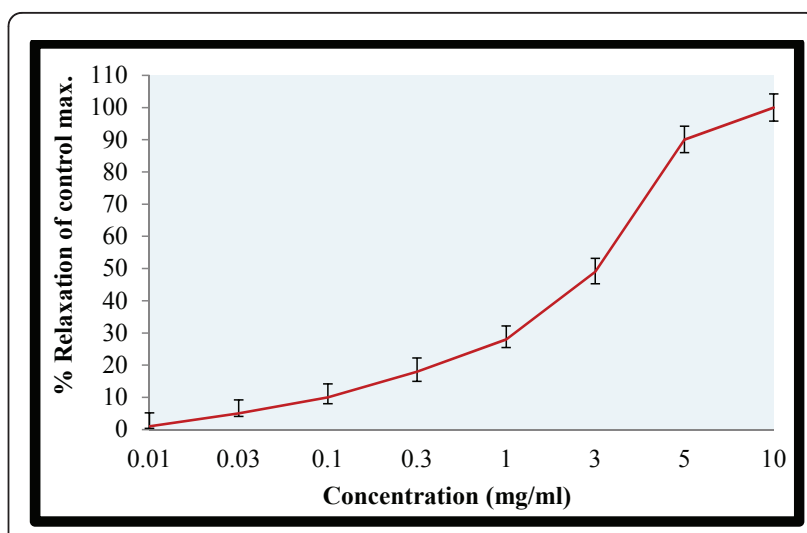

Figure 3 Spasmolytic activity of $M$. africana on spontaneous rabbit's jejunum preparations.

In order to explain the possible mode of actions, we tried the extract on contractions produced by high potassium concentration $(80.0 \mathrm{mM})$. The results are shown in Figure 4. Interestingly, the extract produced similar type of actions in the $\mathrm{KCl}$-induced contractions. The results of the higher concentration are superimposable (Figure 5). Thus the extract is having almost similar values of $\mathrm{EC}_{50}$ for the spontaneous contractions and $\mathrm{KCl}$-induced contractions. Studies have shown that high $\mathrm{KCl}$ induced contractions are due to membrane depolarization of the smooth muscles of intestine. Depolarization of the muscles by $\mathrm{KCl}(80 \mathrm{mM})$ opens the voltage operated calcium channels and allows the extra-cellular calcium into the cytosol $[22,24]$. This is followed by the release of calcium from internal stores that help in sustained contractions. In other word $\mathrm{KCl}$ induced contractions are mediated by both extracellular and intracellular calcium levels [29]. The results suggest that the plant specie is having antispasmodic action possibly through the calcium channel blocking mechanisms [30].

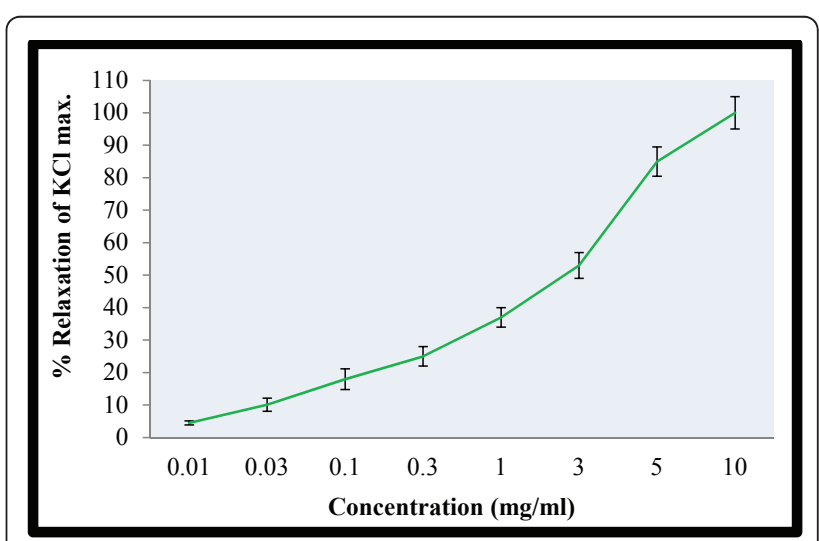

Figure 4 Spasmolytic activity of $M$. africana on $\mathrm{KCl}(80 \mathrm{mM})$ induced contractions on rabbit's jejunum preparations. 


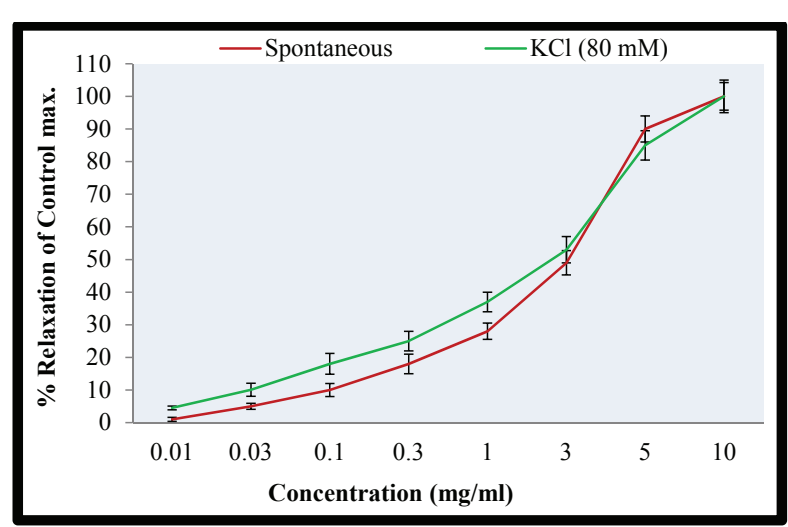

Figure 5 Spasmolytic activity of $M$. africana on spontaneous and $\mathrm{KCl}(80 \mathrm{mM})$ induced contractions on rabbit's jejunum preparations

\section{Conclusion}

The present study reveals the antispasmodic action of crude methanol extract of $M$. africana and isolation of a new steroidal compound "Myrsigenin" from this specie.

\section{Acknowledgements}

The authors are thankful to the Higher Education Commission (HEC) Pakistan for Indigenous 5000 fellowship programme. We are thankful to HEJ research institute, University of Karachi, Pakistan for providing spectroscopic facilities. Many thanks to Prof. Dr. Habib Ahmad, Hazara University, Khyber Pakhtunkhwa for identification of the plant.

\section{Author details}

${ }^{1}$ Pharmabiotech Research Lab, Centre for Biotechnology and Microbiology, University of Peshawar, Peshawar, Khyber Pakhtunkhwa, Pakistan. ${ }^{2}$ Department of Pharmacy, University of Peshawar, Peshawar, Khyber Pakhtunkhwa, Pakistan

\section{Authors' contributions}

SA (PhD research scholar) carried out sampling and experimental work, BA supervised the research work conducted by SA and designed the experimental work and manuscript preparation with the help of SB and SA. The final manuscript is approved by all of the authors after reviewing it critically.

\section{Competing interests}

The authors declare that they have no competing interests.

Received: 1 February 2011 Accepted: 6 July 2011 Published: 6 July 2011

\section{References}

1. Vitalini S, Tomè F, Fico G: Traditional uses of medicinal Plants in Valvestino (Italy). J Ethnopharmacol 2009, 121:106-116.

2. Hamayun M, Khan SA, Iqbal I, Rehman G, Hayat T, Khan MA: Ethnobotanical profile of Utror and Gabral valleys, district Swat, Pakistan. Ethnobotan Leaflets 2005, , 1: article 9.

3. Bashir A, Sadiq A, Shumaila B, Achyut A, Chaudhary MI: Biological activities of a new compound isolated from the aerial parts of Vitex agnus castus L. Afr J Biotechnol 2010, 9:9063-9069.

4. Bashir A, Sadiq A, Shumaila B, Ibrar K, Niaz A, Chaudhary Ml: Phytotoxic, antibacterial and haemagglutination activities of the aerial parts of Myrsine africana L. Afr J Biotechnol 2011, 10:97-102.
5. Bashir A, Sadiq A, Shumaila B, Ibrar K, Achyut A, Chaudhary Ml: Antiinflammatory and enzyme inhibitory activities of a crude extract and pterocarpan isolated from the aerial parts of Vitex agnus castus. Biotechnol J 2010, 5:1207-1215.

6. Nasir E, Ali Sl: Flora of West Pakistan; "Myrsinaceae".Edited by: Jafri SMH, Qaiser S 1979, 89:5.

7. Zabta KS, Ashiq AK, Toshiyuki N: Medicinal plants and other useful plants of District Swat, Pakistan. Al Aziz Press, Peshawar, Pakistan 2003, 79.

8. Kokwaro JO: Medicinal plants of East Africa. Kenya literature Bureau. Nairobi; 2 1993, 401.

9. Beentje HJ: Kenya trees, shrubs and lianas. National museums of Kenya, Nairobi 1994, 722.

10. Desta B: Ethiopian traditional herbal drugs. Part I: Studies on the toxicity and therapeutic activity of local taenicidal medications. J Ethnopharmacol 1995, 45:27-33.

11. Zhong HBC: State administration of traditional Chinese medicine of the people's republic of China. Shanghai Science and Technology Press: Shanghai; 1985:3:245.

12. Abbasi AM, Khan MA, Ahmad M, Zafar M: Herbal Medicines used to cure various ailments by the inhabitants of Abbottabad district, North West Frontier Province, Pakistan. Indian J Trad Know 2010, 9:175-183.

13. Kupchan S, Morris S, Pieter S: Tumor inhibitors xxxv. Myrsine saponin, the active principle of Myrsine africana. J Med Chem 1969, 12:107-169.

14. Gathuma JM, Mbaria JM, Wanyama J, Kaburia HFA, Mpoke L, Mwangi JN, Samburu, Turkana healers: Efficacy of Myrsine africana, A. anthelmintica and $H$. sepalosa herbal remedies against mixed natural sheep helminthosis in Samburu district, Kenya. J Ethnopharmacol 2004, 91:7-12.

15. Manguro ALO, Midiwo JO, Kraus W: A flavonol glycoside from Myrsine africana leaves. Phytochemistry 1996, 43:1107-1109.

16. Manguro LOA, Midiwo JO, Kraus W: Further flavonol glycoside from Myrsine africana. Nat Prod Sci 1997, 3:8-10.

17. Manguro LOA, Midiwo JO, Kraus W: A new flavonol Tetraglycoside from Myrsine africana leaves. Nat Prod Lett 1997, 9:121-126.

18. Manguro LOA, Midiwo JO, Kraus W, Ugi I: Benzoquinone derivatives of Myrsine africana and Maesa lanceolata. Phytochemistry 2003, 64:855-862.

19. Li XH, McLaughlin JO: Bioactive compounds from the roots of Myrsine africana. J Nat Prod 1989, 52:660-662.

20. Manguro LOA, Midiwo JO, Kraus W: Triterpenoids and steroids of Myrsine africana leaves. Planta Medica 1997, 63:290.

21. Qayum A: Isolated Preparations. Guidelines and Instructions. Fundamentals of Experimental Pharmacology. 1 edition. New Awan Printers, Peshawar; 2004, 4.01-4.16.

22. Gilani AH, Bukhari IA, Khan RA, Khan AU, Ullah F, Ahmad VU: Cholinomimetic and Calcium Channel Blocking Activities of Carthamus oxycantha. Phytother Res 2005, 19:679-683.

23. Bashir A, Niaz A, Shumaila B, Sadiq A: Cholinomimatic and calcium channel blocking activity of the aerial parts of T. hirsuta wall. J Chem Soc Pakistan 2009, 31:647-651.

24. Niaz A, Bashir A, Shumaila B, Jehandar S, Sadiq A, Manzoor A: Calcium channel blocking activities of Withania coagulans. Afr J Pharm Pharmacol 2009, 3:439-442.

25. Niaz Ali, Syed WAS: Spasmolytic activity of fruits of Tamarindus indica L. $J$ Young Pharmacists 2010, 2:261-64

26. Farre AJ, Columbo M, Fort M, Gutierrez B: Differential effects of various Ca ${ }^{++}$antagonists. Gen Pharmacol 1991, 22:177-181.

27. Rossum VJM: Cumulative dose response curves II. Techniques for the making of dose response curves in isolated organs and the evaluation of drug parameters. Arc Intern de Pharmacodynamie et de Therapie 1963, 143:299-330.

28. Lecanu L, Yao W, Teper GL, Yao ZX, Greeson J, Papadopoulos V: Identification of naturally occurring spirostenols preventing $\beta$-amyloidinduced neurotoxicity. Steroids 2004, 69:1-16.

29. Grasa L, Rebollar E, Arruebo MP, Plaza MA, Murillo MD: The role of $\mathrm{Ca}^{2+}$ in the contractility of rabbit small intestine in vitro. J Physiol Pharmacol 2005, 55:639-650.

30. Syed WAS, Sameer AK, Waqar A, Niaz A: Spasmogenic, spasmolytic and anti-hypertensive activity of Forskalea tenacissima. Afr J Pharm Pharmacol 2010, 4:381-385. 


\section{Pre-publication history}

The pre-publication history for this paper can be accessed here: http://www.biomedcentral.com/1472-6882/11/55/prepub

doi:10.1186/1472-6882-11-55

Cite this article as: Azam et al: Anti-spasmodic action of crude

methanolic extract and a new compound isolated from the aerial parts

of Myrsine africana. BMC Complementary and Alternative Medicine 2011

11:55.

Submit your next manuscript to BioMed Central and take full advantage of:

- Convenient online submission

- Thorough peer review

- No space constraints or color figure charges

- Immediate publication on acceptance

- Inclusion in PubMed, CAS, Scopus and Google Scholar

- Research which is freely available for redistribution

Submit your manuscript at 